\title{
Probable Risk Factors in Children and Adolescents with Neurodevelopmental and Non-Neurodevelopmental Psychiatric Disorders in a Large Turkish Clinical Sample
}

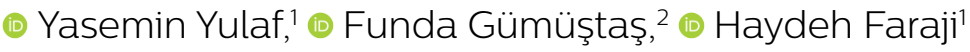

\begin{tabular}{|c|}
\hline $\begin{array}{r}\text { 'Department of Psychology, } \\
\text { Istanbul Gelişim University, } \\
\text { Istanbul, Turkey } \\
\text { 'Department of Child and } \\
\text { Adolescent Psychiatry, Marmara } \\
\text { University, Pendik Training and } \\
\text { Research Hospital, İstanbul, Turkey }\end{array}$ \\
\hline $\begin{array}{r}\text { Submitted: 07.01.2019 } \\
\text { Accepted: 04.04.2019 }\end{array}$ \\
\hline $\begin{array}{r}\text { Correspondence: Yasemin Yulaf, } \\
\text { İstanbul Gelişim Üniversitesi Tıı } \\
\text { Fakültesi, Psikoloji Bölümü, } \\
\text { İstanbul, Turkey } \\
\text { E-mail:yyulaf@gelisim.edu.tr }\end{array}$ \\
\hline 口Fing \\
\hline $\begin{array}{r}\text { Keywords: Adolescents; } \\
\text { children; neurodevelopmental } \\
\text { disorders; } \\
\text { nonneurodevelopmental } \\
\text { psychiatric disorders. }\end{array}$ \\
\hline (c) (i) \$ \\
\hline $\begin{array}{l}\text { This work is licensed under a Creative Commons } \\
\text { Attribution-NonCommercial } 4.0 \text { International License. }\end{array}$ \\
\hline
\end{tabular}

\begin{abstract}
Objective: This study is aimed to compare socio-demographic variables, perinatal characteristics, developmental stages, comorbid medical illnesses between children and adolescents with neurodevelopmental psychiatric disorders and non-neurodevelopmental psychiatric disorders.
\end{abstract}

Methods: In this study, the files of $298 \mathrm{I}$ children and adolescents referred to our, child psychiatry outpatient clinic between January 2015 and September 2016, were examined retrospectively. The data of DSM 5 based psychiatric diagnosis, mean ages, gender, parental work status and education levels, perinatal characteristics, such as a birth week, birth weight, time of speech and walking, frequent comorbid medical conditions such as epilepsy, cardiac disease and asthma, were obtained.

Results: The findings showed that children most often had attention deficit hyperactivity disorder, and anxiety disorders were the second common health problem. The mean ages and working rates of parents, education level of the mothers were significantly lower in children with a neurodevelopmental psychiatric disorder $(n=1502)$ than children with non-neurodevelopmental disorder $(n=690)$ and no psychiatric diagnosis $(n=376)(p<0.05)$. Younger age, male gender, the requirement of neonatal intensive care unit, speech and walking delay and presence of comorbid epilepsy were associated with a neurodevelopmental psychiatric disorder.

Conclusion: Knowing socio-demographic, developmental, medical and perinatal variables associated with neurodevelopmental and non-neurodevelopmental psychiatric disorders may help us to develop preventive interventions.

\section{INTRODUCTION}

There is a rapid psychological and physiological developmental process in childhood and adolescence. It is important to know and prevent risk factors that adversely affect the mental health of children and adolescents concerning community health. ${ }^{\left[{ }^{[]}\right.}$Psychiatric problems may occur in the early stages of life and they are one of the primary elements that may cause loss of functionality. ${ }^{[2]}$ Psychiatric disorders are often treated with appropriate approaches in children and adolescents by child psychiatrists such that their social and academic functions can be improved.

Worldwide epidemiologic studies have shown that children and adolescents between the ages of 0 and 18 years' experience psychiatric disorders at rates ranging from $9 \%$ to $21 \%$. However, epidemiologic data for Turkey are very limited. The Mental Health Profile of Turkey study reported that psychopathology rates based on parental reports were $11.3 \% .^{[3]}$

Neurodevelopmental disorders (NDD) occur in the early stages of development and usually overlap each other. Intellectual disability, autism spectrum disorders, attentiondeficit/hyperactivity disorder (ADHD), special learning disorders, motor coordination, and tic and communication disorders count among the defined NDD. ${ }^{[4]}$ Different risk factors have been reported for different NDD diagnoses. Sagiv et al ${ }^{[5]}$ reported associations between socioeconomic difficulties and prenatal exposures and ADHD. Although parental age, gestational age, parity, and socioeconomic level are not risk factors, parental psychopathology and prenatal environmental factors predict autism. ${ }^{[6]} \mathrm{A}$ recent systematic review and meta-analysis stated that ad- 
vanced parental age was associated with an increased risk of autism in the offspring. ${ }^{[7]}$ Maternal illiteracy, maternal history of pregnancy loss, and preterm birth are predictive factors for mental retardation. ${ }^{[8]}$

Apart from NDD, the most common psychiatric diagnoses in children and adolescents are disruptive behavior disorders, such as oppositional defiant disorder and conduct disorder and internalizing disorders, such as anxiety disorder and depression. ${ }^{[9-11]}$ Previous studies have investigated the risk factors of non-neurodevelopmental psychiatric disorders (NNDD), which represent internalizing and/or externalizing disorders. Studies have shown that low socioeconomic level, maternal anxiety disorder, and female gender are risk factors for internalizing disorders. ${ }^{[12-14]}$ Perinatal complications, maternal depression, and male gender are risk factors for externalizing disorders. ${ }^{[10,15]}$

It is acknowledged that the effects of mental problems that start in childhood are not limited to childhood and adolescence; they also extend into adulthood. ${ }^{[2]}$ Gaining information about the distribution, prevalence, and risk factors of mental problems in children and adolescents have major importance for taking preventive measures and determining treatment areas.

We hypothesized that male gender, preterm birth, low birth weight, speech and walking delay, advanced parental age, low socioeconomic status of parents, such as low educational levels and high unemployment rates predict the diagnosis of NDD in children and adolescents. In this study, we aimed to compare sociodemographic variables, developmental stages, perinatal characteristics, and other comorbid medical conditions between children with NDD, NNDD, and no diagnosis of psychiatric disorders.

\section{MATERIALS AND METHODS}

\section{Participants}

The sample of this study comprised children and adolescents between the ages of 6 and 17 years who were referred to the child and adolescent psychiatry outpatient clinic at state hospital between January 2015 and September 2016 .

\section{Procedure}

Information about sociodemographic variables, such as age, sex, parents' ages, education levels and work status, perinatal characteristics, such as birth weight, birth week, history of staying in a neonatal intensive care unit (NICU), developmental stages, Diagnostic and Statistical Manual of Mental Disorders, Fifth Edition (DSM-5)-based psychiatric diagnosis, and presence of comorbid medical illness were retrospectively obtained from the children's files.

Children with intellectual disability, autism spectrum disorders, ADHD, special learning disorders, motor and communication disorders were included in the NDD group. Children with any anxiety, depressive, and disruptive be- havior disorders were defined as children with NNDD. Patients who presented to the outpatient clinic at similar dates and were not diagnosed as having any psychiatric disorder were included in the control group.

Children diagnosed as having psychosis $(n=10)$, obsessivecompulsive disorder $(n=67)$, elimination disorders $(n=93)$, somatic symptom disorders $(n=I I)$, eating disorders $(n=2)$, gender dysphoria $(n=6)$, sleep disorders $(n=82)$, traumarelated disorders $(n=55)$, and substance-related disorders $(n=9)$ were excluded from this study. We aimed to reduce confounding factors by keeping narrow the range of diagnosis. We also excluded the children and adolescents with a diagnosis of both NDD and NNDD $(n=81)$.

\section{Statistical analysis}

Descriptive statistics, such as percentage, mean, standard deviation, were obtained using the SPSS 20.00 program. The Chi-square test was used to evaluate categorical data. For the comparison of normally distributed continuous variables in more than two groups, analysis of variance (ANOVA) was used. Variables that predicted NDD and NNDD were analyzed using logistic regression analysis. The results were evaluated at $95 \%$ confidence intervals and 0.05 significance level.

\section{RESULTS}

The mean age of $298 \mathrm{I}$ children and adolescents was $9.8 \pm 3.2$ ( $\min 6, \max 17)$ years. Sixty percent of the cases $(n=1793)$ were males. Forty-three percent of the children and adolescents were diagnosed as having ADHD $(n=1231)$. The second most common diagnosis was anxiety disorders ( $13.9 \%, n=424)$. The distribution of psychiatric diagnoses, according to DSM-5 is shown in Table I.

The mean age of patients with one of the NDD diagnoses $(n=1502)$ was significantly lower than in children and adolescents in the NNDD group $(n=690)$ and the control group $(n=376)$. The rate of male patients in the NDD group was significantly higher than in the other two groups. The average ages of the mothers and fathers of children and adolescents with NDD were significantly lower than in the NNDD group and controls. The working ratios and education levels of the mothers of children and adolescents with NDD were significantly lower than in the other groups (Table 2).

Although there was no difference between the groups concerning birth week and birth weight, children with NDD had significantly higher rates of staying in neonatal intensive care units than in the other groups. Speech and walking time of children with NDD were later than in the other two groups. Heart disease was significantly more prevalent in the NNDD group, and epilepsy was more frequent in the NDD group (Table 3). It was shown that $32.8 \%(n=64)$ of children and adolescents with epilepsy were comorbid with ADHD. In the NNDD group, 3.1\% $(n=18)$ of internalizing disorders and $1.7 \%(n=3)$ of externalizing disorders were accompanied by cardiac disease $(p=0.043)$. 
Table I. Distribution of psychiatric diagnoses according to DSM-5

\begin{tabular}{lcc}
\hline & $\mathbf{n}$ & $\%$ \\
\hline No psychiatric diagnosis & 376 & 12.6 \\
Neurodevelopmental disorders & & \\
$\quad$ Intellectual disability & 282 & 9.4 \\
$\quad$ Autism spectrum disorders & 70 & 2.3 \\
$\quad$ Attention-deficit/hyperactivity disorder & & \\
$\quad$ Predominately inattentiveness type & 471 & 15.8 \\
$\quad$ Predominately hyperactivity type & 168 & 5.6 \\
$\quad$ Combined type & 592 & 19.8 \\
$\quad$ Learning disorders & 80 & 2.7 \\
$\quad$ Tic disorders (Motor disorders) & 104 & 3.5 \\
$\quad$ Communication disorders & 107 & 3.6 \\
Psychosis & 10 & 0.3 \\
Bipolar disorder & 10 & 0.3 \\
Depression & 101 & 3.4 \\
Anxiety disorders & 424 & 14.2 \\
Obsessive compulsive disorder & 67 & 2.2 \\
Trauma related disorders & 55 & 1.8 \\
Somatic symptom disorder & 11 & 0.4 \\
Eating disorders & 2 & 0.1 \\
Elimination disorders & 93 & 3.1 \\
Sleep disorders & 82 & 2.7 \\
Gender dysphoria & 6 & 0.2 \\
Disruptive behavior disorders & 9.9 & 0.3 \\
Substance-related disorders & & \\
\hline & & \\
\hline
\end{tabular}

Note: Some cases have more than one diagnosis so the number of cases is more than the number of samples.
According to logistic regression analysis, younger age, male gender, history of staying in an NICU, presence of speech and walking delay and epilepsy were predictive for NDD, whereas older age and female sex were predictive for NNDD (Table 4). Significantly more girls had internalizing disorders $(n=356,59.4 \%)$ compared with externalizing disorders $(n=54,27.3 \%)$ in the NNDD group $(p<0.001)$.

\section{DISCUSSION}

In our study, the DSM-5-based psychiatric disorders of children and adolescents between the ages of 6 and 17 years who referred to the child and adolescent psychiatry outpatient clinic over a two-year period were retrospectively reviewed. The present study aims to investigate the differences in sociodemographic variables, developmental stages, perinatal characteristics, and other comorbid medical conditions of children and adolescents with NDD, NNDD and children and adolescents with no diagnosis of psychiatric disorders to identify variables that predict NDD and NNDD.

We found that children and adolescents were most commonly diagnosed as having ADHD at a rate of $41 \%$, followed by anxiety disorders. In studies conducted in clinical samples in our country, Turkey, it has been reported that ADHD is the most common diagnosis, similar to our study. $[2,16]$ In an American study, it was shown that externalizing disorders, such as ADHD and/or behavior disorders, were the most frequently diagnosed, followed by internalizing disorders in an outpatient child psychiatry clinic. ${ }^{[17]}$

Table 2. Comparison of sociodemographic variables between the groups

\begin{tabular}{|c|c|c|c|c|c|}
\hline & $\begin{array}{c}\text { CG } \\
(n=376)\end{array}$ & $\begin{array}{c}\text { NDD } \\
(n=1502)\end{array}$ & $\begin{array}{c}\text { NNDD } \\
(n=690)\end{array}$ & $\mathbf{F} / \chi^{2}$ & $\mathbf{p}$ \\
\hline Age $($ mean $\pm S D)$ & $11.56 \pm 3.72$ & $9.34 \pm 2.74$ & $10.92 \pm 3.30$ & 113.97 & $<0.001^{* * * *}$ \\
\hline Sex (male), n (\%) & $192(51.1)$ & $1062(70.7)$ & $332(48.1)$ & 123.49 & $<0.001^{* * * *}$ \\
\hline Maternal age $($ mean $\pm S D)$ & $38.05 \pm 6.77$ & $35.76 \pm 6.30$ & $37.75 \pm 13.70$ & 16.21 & $<0.001^{* * * *}$ \\
\hline Maternal work status: employed & $130(36.1)$ & $311(21.6)$ & $174(26.6)$ & 39.25 & $<0.001^{* * * *}$ \\
\hline \multicolumn{6}{|l|}{ Maternal education } \\
\hline Illiterate & $13(3.6)$ & $80(5.6)$ & $22(3.4)$ & 35.11 & $<0.001^{* * * *}$ \\
\hline Primary school & $146(40.5)$ & $737(5 \mid .5)$ & $329(50.2)$ & & \\
\hline Secondary school & $34(9.4)$ & $151(10.6)$ & 75 ( 11.4$)$ & & \\
\hline High school & $110(30.6)$ & $332(23.2)$ & $147(22.4)$ & & \\
\hline University & $57(15.8)$ & $|3|(9.2)$ & $83(12.7)$ & & \\
\hline Paternal age (mean $\pm S D)$ & $41.83 \pm 6.87$ & $39.78 \pm 6.51$ & $41.35 \pm 6.99$ & 19.69 & $<0.001^{\text {*ak }}$ \\
\hline Paternal work status: employed & $335(94.6)$ & $1344(94.8)$ & $6 I I(93.1)$ & 19.53 & $0.034^{*}$ \\
\hline \multicolumn{6}{|l|}{ Paternal education } \\
\hline Illiterate & $4(1.1)$ & $13(0.9)$ & $7(1.1)$ & 24.66 & $0.006^{* *}$ \\
\hline Primary school & $125(35.5)$ & $640(45.5)$ & $285(44.3)$ & & \\
\hline Secondary school & $37(10.5)$ & $173(12.4)$ & $67(10.4)$ & & \\
\hline High school & $103(29.3)$ & $372(26.4)$ & $165(25.7)$ & & \\
\hline University & $83(23.6)$ & $209(14.9)$ & $119(18.5)$ & & \\
\hline
\end{tabular}


Table 3. Comparison of groups concerning perinatal characteristics, developmental stages, and comorbid medical illnesses

\begin{tabular}{|c|c|c|c|c|c|}
\hline & $\begin{array}{c}\text { CG } \\
(n=376)\end{array}$ & $\begin{array}{c}\text { NDD } \\
(n=\mid 502)\end{array}$ & $\begin{array}{c}\text { NNDD } \\
(n=690)\end{array}$ & $\chi^{2}$ & $\mathbf{p}$ \\
\hline Preterm birth & $20(7.4)$ & $97(9.3)$ & $34(7.1)$ & 2.58 & 0.275 \\
\hline \multicolumn{6}{|l|}{ Birth weight } \\
\hline$<1500 \mathrm{~g}$ & $4(1.5)$ & $29(2.9)$ & $6(1.3)$ & 5.23 & 0.264 \\
\hline $1500-2500 \mathrm{~g}$ & $24(8.8)$ & $81(8.0)$ & $44(9.2)$ & & \\
\hline$>2500 \mathrm{~g}$ & 244 (89.7) & $898(89.1)$ & $428(89.5)$ & & \\
\hline Staying in NICU & $24(9.1)$ & $134(12.9)$ & $40(8.4)$ & 10.73 & $0.03^{*}$ \\
\hline Speech delay & $8(2.8)$ & $119(10.5)$ & $12(2.3)$ & 95.14 & $<0.001^{* *}$ \\
\hline Walking delay & $12(3.7)$ & $137(10.2)$ & $15(2.5)$ & 76.77 & $<0.001^{* *}$ \\
\hline Asthma & $24(6.7)$ & $1006.8)$ & $50(7.6)$ & 0.51 & 0.775 \\
\hline Heart disease & $7(1.9)$ & $19(1.3)$ & $19(2.9)$ & 6.11 & $0.047^{*}$ \\
\hline Epilepsy & $17(4.7)$ & $97(6.6)$ & $24(3.7)$ & 8.62 & $0.013^{*}$ \\
\hline
\end{tabular}

${ }^{*}<<0.05 ; *^{*}$ < 0.001 . CG: Control group; NDD: Neurodevelopmental disorders; NNDD: Non-neurodevelopmental disorders; NICU: Neonatal intensive care unit.

Table 4. Variables that predict the presence of neurodevelopmental disorders and non-neurodevelopmental disorders

\begin{tabular}{|c|c|c|c|c|c|c|c|}
\hline & B & S.E. & Wald & df & Sig. & $\operatorname{Exp}(B)$ & $95 \% \mathrm{CI}$ \\
\hline \multicolumn{8}{|l|}{ NDD } \\
\hline Age & -0.140 & 0.023 & 38.345 & 1 & $<0001^{* *}$ & 0.869 & $0.83-0.89$ \\
\hline Sex (male) & -1.124 & 0.126 & 79.568 & I & $<0.001^{* *}$ & 0.325 & $0.26-0.42$ \\
\hline Staying in NICU & 1.031 & 0.456 & 5.115 & 1 & $0.024^{*}$ & 0.927 & $0.62-0.94$ \\
\hline Speech Delay & 0.513 & 0.123 & 17.553 & 1 & $<0.001^{* *}$ & 1.671 & $1.35-2.12$ \\
\hline Walking delay & 0.425 & 0.116 & 13.432 & 1 & $<0.001^{* *}$ & 1.529 & $1.23-1.88$ \\
\hline Epilepsy & 0.651 & 0.298 & 4.759 & 1 & $0.029^{*}$ & 0.522 & $0.27-0.83$ \\
\hline Constant & 1.646 & 1.363 & 1.459 & 1 & 0.227 & 5.187 & \\
\hline \multicolumn{8}{|l|}{ NNDD } \\
\hline Age & 0.069 & 0.024 & 8.317 & 1 & $0.004^{*}$ & 0.947 & $0.91-0.98$ \\
\hline Sex (Female) & 1.056 & 0.132 & 63.864 & 1 & $<0.001^{* *}$ & 1.154 & $1.12-1.48$ \\
\hline Constant & -0.154 & 1.440 & 0.011 & 1 & 0.915 & 0.857 & \\
\hline
\end{tabular}

${ }^{*} \mathrm{p}<0.01 ;{ }^{*} \mathrm{p}<0.001$. NDD: Neurodevelopmental disorders; NNDD: Non-neurodevelopmental disorders; NICU: Neonatal intensive care unit; S.E.: Standard error.

The mean age of children and adolescents with NDD was lower than in children and adolescents with NNDD and those with no diagnosis of psychiatric disorders (CG); younger age was found to predict NDD in our study. Our findings suggest that children and adolescents with NDD may need support from psychiatric services at much earlier ages than children and adolescents with NNDD.

We found that the rate of male children was significantly higher in the NDD group than in the other groups. The higher ratio of girls in the NNDD group was related to internalizing disorders. It was shown that internalizing disorders, such as depression, anxiety, and somatic symptoms, were seen more commonly in girls than boys in many studies, similar to our study. ${ }^{[14]}$ Olofsdotter et al. ${ }^{[10]}$ reported that girls had three times more anxiety disorders than boys. In another study, disruptive behavior disorders were found to be three times more common in boys than in girls. ${ }^{[18]}$ Consistent with our study, Sauver et al. ${ }^{[19]}$ showed that the male gender was a significant risk factor for ADHD.
In our study, as socioeconomic and sociocultural level indicators, the average age, working status, and educational level of the parents were examined to ascertain if there were differences between the three groups. Similar to our findings, Fidan found that working rates of mothers in the NDD group were lower than mothers in the NNDD group and controls. ${ }^{[I]}$ The education levels of the parents of children and adolescents with NDD were examined. Parents in the NDD group were most commonly primary school graduates and had lower educational levels than the other two groups. These results are similar to the results of previous studies in Turkey. ${ }^{[16,20]}$ It has been reported that primary school graduate mothers exhibited extreme protective attitudes and stricter discipline towards their children, and as education levels increased, child-rearing attitudes of mothers tended to become less conventional. Thus, parental education level becomes a risk factor in the development of psychopathology. ${ }^{[20]}$ Froehlich et al. ${ }^{[21]}$ suggested that the frequency of ADHD in children of lowincome families might increase due to high prenatal, congenital, and environmental risk factors. 
The need for NICU treatment was higher in the NDD group than in the other groups in the present study. There were no significant differences between the groups concerning birth time and birth weight. Thapar et al. offered that premature birth might be the most probable factor despite the inadequacy of evidence on behalf of possible determinants of ADHD. ${ }^{[22]}$ Sciberras et al. ${ }^{[23]}$ found that prematurity, especially extreme prematurity, had the strongest relationship with ADHD. According to Lorenz et al.,. ${ }^{[2]]}$ preterm infants are at increased risk for neurodevelopmental disorders, including motor, sensory, cognitive, and other brain disorders.

In our study, the findings showed that children with NDD had more speech and walking delays compared with the other two groups, and these delays predicted NDD. Our findings are consistent with the results of studies conducted in groups of children aged I-2 years and over two years, showing that children with NDD have more cognitive dysfunction, motor disorders, language and other disorders of learning, but inconsistent with a study that examined children aged under one year. ${ }^{[25,26]}$

When we compared groups concerning other comorbid medical illnesses, it was found that the rates of heart disease were significantly higher in the NNDD group. In parallel with our findings, some studies suggest that anxiety disorders are a psychiatric disorder, which may also be a risk factor for cardiovascular diseases. ${ }^{[2]}$ McLaughlin et al. ${ }^{[28]}$ suggested that there was an association between psychosocial stressors and internalizing disorders but not externalizing disorders. Sex differences are present in the extent to which vagal tone moderates the relationship between stressors and internalizing psychopathology, such that low vagal tone is associated with heightened stressrelated vulnerability, particularly among males.

When we compared the groups regarding the presence of epilepsy, which is a common comorbid medical illness, epilepsy was more frequent in the NDD than the other two groups and the presence of epilepsy predicted NDD. In addition, we found that $32 \%$ of the children and adolescents with epilepsy were also diagnosed as having ADHD. The rate of ADHD as a comorbidity in children and adolescents with epilepsy was reported ranging from $1.6 \%$ to $54 \% .{ }^{[29]}$ In a study examining accompanying psychiatric disorders in children with epilepsy, it was emphasized that the rate of ADHD in children with epilepsy was $29.1 \%$, which was higher than in the normal population. ${ }^{[30]}$ Gürkan et al. ${ }^{[3]}$ showed that $48 \%$ of patients had at least one psychiatric diagnosis and the most common diagnosis was ADHD (17.2\%) among 64 children and adolescents with epilepsy aged between 5 and 18 years. Brikell et al. ${ }^{[32]}$ found that individuals with epilepsy had a 3.5 -fold increased risk of ADHD compared with the individuals without epilepsy.

The lack of detailed assessment of sociodemographic data of children and families in our study, the lack of structured scales, retrospective file scanning, and the use of data from a single-center can be considered as limitations of our research. However, despite our limitations, we think that our study is a comprehensive study comparing children with neurodevelopmental disorders and non-neurodevelopmental disorders concerningsociodemographic, perinatal, developmental features, and accompanying medical conditions. The collaboration of experts from different disciplines is important during the monitoring and evaluation process of psychiatric disorders in children and adolescents.

\section{CONCLUSION}

In our study, it was found that ADHD was the most common diagnosis in children and adolescents referred to the child and adolescents psychiatry outpatient clinic. Younger age, male gender, the requirement of NICU treatment, speech and walking delays, and presence of comorbid epilepsy were shown to be predictors of NND. Female gender and older age were the predictive variables of NNDD and cardiac diseases were more frequently accompanying in this group. It is thought that our findings will contribute to developing appropriate interventions across psychiatric problems by taking these parameters into account in children and adolescents referred to outpatient clinics.

Informed Consent

\section{Retrospective study.}

Peer-review

Internally peer-reviewed.

Authorship Contributions

Concept: Y.Y.; Design: Y.Y.; Supervision: Y.Y., H.F; Fundings: Y.Y.; Materials: Y.Y.; Data: F.G., Y.Y.; Analysis: F.G., Y.Y.; Literature search: Y.Y., H.F.; Writing: H.F., F.G.; Critical revision: F.G.

\section{Conflict of Interest}

None declared.

\section{REFERENCES}

1. Fidan TY. Assessment of Mental Symptoms and Risk Factors in Children and Adolescents Who Admitted to the Child-Adolescent Psychiatry Clinic. Konuralp Medical Journal 2011;31:25-6.

2. Durukan I, Karaman D, Kara K, Türker T, Tufan AE, Yalçın Ö, et al. Diagnoses of patients referring to a child and adolescent psychiatry outpatient clinic. Dusunen Adam 2011;24:113-20. [CrossRef]

3. Dursun OB, Güvenir T, Özbek A. Epidemiologic Studies in Child and Adolescent Psychiatry: A Review of Methodology. Curr Opin Psychiatry 2010;2:401-16.

4. American Psychiatric Association. Diagnostic and statistical manual of mental disorders. 5th ed. Arlington, VA: American Psychiatric Publishing; 2013. [CrossRef]

5. Sagiv SK, Epstein JN, Bellinger DC, Korrick SA. Pre- and postnatal risk factors for ADHD in a nonclinical pediatric population. J Atten Disord 2013;17:47-57. [CrossRef]

6. Larsson HJ, Eaton WW, Madsen KM, Vestergaard M, Olesen AV, Agerbo E, et al. Risk factors for autism: perinatal factors, parental psychiatric history, and socioeconomic status. Am J Epidemiol 2005;161:916-25. [CrossRef]

7. Wu S, Wu F, Ding Y, Hou J, Bi J, Zang Z. Advanced parental age and autism risk in children: a systematic review and meta-analysis. Acta 
Psychiatr Scand 2017;135:29-41. [CrossRef]

8. Durkin MS, Khan NZ, Davidson LL, Huq S, Munir S, Rasul E, et al. Prenatal and postnatal risk factors for mental retardation among children in Bangladesh. Am J Epidemiol 2000;152:1024-33.

9. Canino G, Polanczyk G, Bauermeister JJ, Rohde LA, Frick PJ. Does the prevalence of CD and ODD vary across cultures? Soc Psychiatry Psychiatr Epidemiol 2010;45:695-704. [CrossRef]

10. Olofsdotter S, Vadlin S, Sonnby K, Furmark T, Nilsson KW. Anxiety disorders among adolescents referred to general psychiatry for multiple causes: clinical presentation, prevalence and comorbidity. Scand J Child Adolesc Psychiatr Psychol 2016;4:55-64. [CrossRef]

11. Karacetin G, Arman AR, Fis NP, Demirci E, Ozmen S, Hesapcioglu ST, et al. Prevalence of Childhood Affective disorders in Turkey: An epidemiological study. J Affect Disord 2018;238:513-21. [CrossRef]

12. Swartz JR, Hariri AR, Williamson DE. An epigenetic mechanism links socioeconomic status to changes in depression-related brain function in high-risk adolescents. Mol Psychiatry 2017;22:209-14.

13. Newman L, Judd F, Olsson CA, Castle D, Bousman C, Sheehan P, et al. Early origins of mental disorder-risk factors in the perinatal and infant period. BMC Psychiatry 2016;16:270. [CrossRef]

14. Zahn-Waxler C, Klimes-Dougan B, Slattery MJ. Internalizing problems of childhood and adolescence: prospects, pitfalls, and progress in understanding the development of anxiety and depression. Dev Psychopathol 2000;12:443-66. [CrossRef]

15. Grizenko N, Pawliuk N. Risk and protective factors for disruptive behavior disorders in children. Am J Orthopsychiatry 1994;64:534-44.

16. Sar1 BA. Symptoms and Diagnosies of Patients Referring to A Child and Adolescent Psychiatry Outpatient Clinic in Batman. J Clin Psy 2013;16:7-17.

17. Staller JA. Diagnostic profiles in outpatient child psychiatry. Am J Orthopsychiatry 2006;76:98-102. [CrossRef]

18. Benenson JF. The Cambridge Encyclopedia of Child Development. In: Hopkins B, Barr RG, Michel GF, Rochat P, editors. Sex differences. Cambridge: Cambridge University Press, UK; 2005. p. 36674.

19. St Sauver JL, Barbaresi WJ, Katusic SK, Colligan RC, Weaver AL, Jacobsen SJ. Early life risk factors for attention-deficit/hyperactivity disorder: a population-based cohort study. Mayo Clin Proc 2004;79:1124-31. [CrossRef]

20. Demirkaya SK, Abalı O. The relationship between child rearing attitudes of mothers and problematic behaviors in their preschool period children. Anatolian J Psychiatry 2012;13:67-74.
21. Froehlich TE, Lanphear BP, Epstein JN, Barbaresi WJ, Katusic SK, Kahn RS. Prevalence, recognition, and treatment of attention-deficit/ hyperactivity disorder in a national sample of US children. Arch Pediatr Adolesc Med 2007;161:857-64. [CrossRef]

22. Thapar A, Cooper M, Eyre O, Langley K. Practitioner review: what have we learnt about the causes of ADHD? J Child Psychol Psychiatry 2013;54:3-16. [CrossRef]

23. Sciberras E, Mulraney M, Silva D, Coghill D. Prenatal risk factors and the etiology of ADHD-review of existing evidence. Curr Psychiatry Rep 2017;19:1. [CrossRef]

24. Lorenz JM, Wooliever DE, Jetton JR, Paneth N. A quantitative review of mortality and developmental disability in extremely premature newborns. Arch Pediatr Adolesc Med 1998;152:425-35.

25. Oerbeck B, Overgaard KR, Aspenes ST, Pripp AH, Mordre M, Aase $\mathrm{H}$, et al. ADHD, comorbid disorders and psychosocial functioning: how representative is a child cohort study? Findings from a national patient registry. BMC Psychiatry 2017;17:23. [CrossRef]

26. Korrel H, Mueller KL, Silk T, Anderson V, Sciberras E. Research Review: Language problems in children with Attention-Deficit Hyperactivity Disorder - a systematic meta-analytic review. J Child Psychol Psychiatry 2017;58:640-54. [CrossRef]

27. Brugnera AC, Zarbo R, Adorni GA, Giorgio AT, Rabboni M, Bondi E, et al. Cortical and cardiovascular responses to acute stressors and their relations with psychological distress. Int J Psychophysiol 2017;114:38-46. [CrossRef]

28. McLaughlin KA, Rith-Najarian L, Dirks MA, Sheridan MA. Low vagal tone magnifies the association between psychosocial stress exposure and internalizing psychopathology in adolescents. J Clin Child Adolesc Psychol 2015;44:314-28. [CrossRef]

29. Schubert R. Attention deficit disorder and epilepsy. Pediatr Neurol 2005;32:1-10. [CrossRef]

30. Thome-Souza S, Kuczynski E, Assumpcao F Jr, Rzezak P, Fuentes D, Fiore $\mathrm{L}$, et al. Which factors may play a pivotal role on determining the type of psychiatric disorder in children and adolescents with epilepsy? Epilepsy Behav 2004;5:988-94. [CrossRef]

31. Gürkan K, Tüzün Ü. Psychiatric referral and treatment in children and adolescents with epilepsy. Bull Clin Psychopharmacol 2006;16:22-30.

32. Brikell I, Ghirardi L, D'Onofrio BM, Dunn DW, Almqwist C, Dalsgaard S, et al. Familial Liability to Epilepsy and Attention Deficit/ Hyperactivity Disorder: A Nationwide Cohort Study. Biol Psychiatry 2018;83:173-80. [CrossRef]

\section{Geniş Bir Türk Klinik Örnekleminde Nörogelişimsel ve Nörogelişimsel Olmayan Psikiyatrik Bozukluklu Çocuk ve Ergenlerde Olası Risk Faktörleri}

Amaç: Bu çalışmada, nörogelişimsel psikiyatrik bozukluk tanısı alan çocuk ve ergenler ile nörogelişimsel olmayan psikiyatrik bozukluğu olanların sosyodemografik değişkenler, perinatal özellikler, gelişim evreleri ve eşlik eden tıbbi hastalıklar açısından karşılaştırılması amaçlanmıştır.

Gereç ve Yöntem: Çocuk psikiyatri polikliniğine Ocak 2015-Eylül 2016 tarihleri arasında başvuran 298I çocuk ve ergenin dosyaları geriye dönük olarak incelendi. DSM 5 temelli psikiyatrik tanı verileri, yaş, cinsiyet, ebeveyn çalışma durumu ve eğitim düzeyleri, doğum haftası, doğum ağırlı̆̆ı, konuşma süresi ve yürüme gelişimi gibi perinatal özellikler, epilepsi, kalp hastalığı ve astım gibi sık görülen eşlik eden tıbbi durumlar incelendi.

Bulgular: Çocuklarda en sık dikkat eksikliği hiperaktivite bozukluğu tanısı ve ikinci sıklıkta anksiyete bozuklukları vardı. Nörogelişimsel psikiyatrik bozukluğu $(n=1502)$ olan çocuklarda anne babaların ortalama yaşları, çalışma oranı ve annelerin eğitim düzeyi, nörogelişimsel olmayan psikiyatrik bozukluğu olan $(n=690)$ ve psikiyatrik tanısı olmayan $(n=376)$ çocuklardan anlamlı olarak daha düşüktü $(p<0.05)$. Daha küçük yaş, erkek cinsiyet, yenidoğan yoğun bakım gereksinimi, konuşma ve yürüme gecikmesi ve komorbid epilepsi varlığı nörogelişimsel psikiyatrik bozukluk ile ilişkiliydi.

Sonuç: Nörogelişimsel ve nörogelişimsel olmayan bozukluklar ile ilişkili sosyodemografik, gelişimsel, tıbbi ve perinatal değişkenleri bilmek, koruyucu müdahaleler geliştirmemize yardımcı olabilir.

Anahtar Sözcükler: Çocuklar; ergenler; nörogelişimsel olmayan psikiyatrik bozukluklar; nörogelişimsel psikiyatrik bozukluklar. 